\title{
Perancangan Interaksi Pengguna (User Interaction Design) Menggunakan Metode Prototyping
}

\author{
Rina Candra Noor Santi ${ }^{1}$, Anida Fitriyah ${ }^{2}$ \\ ${ }^{1}$ Prodi Teknik Informatika, Universitas Stikubank, Semarang \\ ${ }^{2}$ Prodi Teknik Informatika, Universitas Islam Negeri Jakarta \\ Rina_cs@lec.unisbank.edu
}

\begin{abstract}
ABSTRAK
Maraknya perdagangan secara online menjadi tantangan bagi pengembang desain antarmuka pengguna untuk mebuat desain yang menarik minat pengunjung untuk melakukan transaksi. Pendekatan User-Centered Design (UCD) melibatkan pengguna sejak tahap analisa, desain, testing, build/redesign. Pada penelitian ini pengembang menerapkan 8 aturan emas perancangan antarmuka pengguna sebagai panduan dalam mendesain antarmuka. Model konseptual dibuat dengan orientasi proses yang terdiri dari proses melihat dan memilih produk yang diterapkan dalam bentuk gallery. Proses pemesanan produk diterapkan pada menu Order. Hasil dari perancangan ini adalah sebuah prototipe yang memiliki ketepatan yang tinggi (high fidelity prototype), yang dibuat dengan software Coreldraw.
\end{abstract}

Kata kunci : UCD, high fidelity prototype, conceptual model, process-oriented.

\begin{abstract}
The rise of online trading is a challenge for developers of user interface design for producing designs that attract visitors to make transactions. Approach of User-Centered Design (UCD) involve users from the analysis stage, design, testing, build / redesign. In this study, developer applying the 8 golden rules of user interface design as a guide in designing the interface. The conceptual model is made with a process orientation which is composed of the view and choose products that are applied in the form of gallery. Product ordering process applied to the Order menu. The results of this design is a prototype that has a high accuracy (high fidelity prototype), made with CorelDraw software.
\end{abstract}

Keywords : UCD, high fidelity prototype, conceptual model, process-oriented 


\section{PENDAHULUAN}

Pada era modern sekarang ini teknologi sangatlah memberi pengaruh yang cukup besar dalam bidang usaha. Hal ini terlihat pula dalam bidang penjualan barang - barang, hal ini dikarenakan karena sistem pemasaran dari sebuah penjualan barang jasa maupun yang lainnya akan terus menerus berkembang sehingga persaingan di dunia perdagangan menjadi semakin ketat. Agar dapat bersaing dengan para pebisnis lain di bidang yang sama, para pengusaha harus bisa memasarkan produknya ke setiap kalangan masyarakat dengan efisien. Salah satu cara yang dianggap cukup efisien dalam memasarkan sebuah produk adalah dengan menggunakan media internet.

Maka, CakeCorner.com pun memanfaatkan internet ini untuk lebih memperluas jangkauan penjualannya.Toko kue ini lebih fokus untuk mengenalkan produknya melalui website yang ia bikin. Website ini diharapkan dapat memberikan informasi tentang penjualan dan melihat daftar pembeli tanpa harus mencatat siapa sajakah pemesannya.

Banyak sekali website yang menyediakan beragam informasi, tetapi banyak diantaranya website yang tidak dapat memenuhi pengguna karena berbagai macam hal dan tujuan awal pembuatan website tersebut, bahkan ada yang mengecewakan penggunanya dan tidak merasa puas.Untuk menghindari itu,maka CakeCorner.com menggunakan sudut pandang UCD (user centered design).[1].

\section{TINJAUAN PUSTAKA}

\subsection{User Centered Design}

Salah satu pendekatan dalam merancang antarmuka pengguna adalah User Centered Design (UCD) yang melibatkan pengguna pada proses desain. Pengguna terlibat sejak tahap analisis awal kebutuhan pengguna untuk pengujian dan evaluasi [1].
Konsep UCD yaitu "In user centered design, the users are the center focus."

Maksud dari pernyataan di atas adalah tujuan/ sifat-sifat, konteks, penguna, sifat konteks dan lingkungan produk semua didasarkan dari pengalaman penguna. Selanjutnya ditetapkan model pekerjaan pengguna yang akan didukung sistem.

Tahapan dalam UCD mencakup [1] :

1. Memahami kebutuhan user.

2. Mendeskripsikan kebutuhan user.

3. Merancang prototype sebagai alternatif

4. Mengevaluasi perancangan.

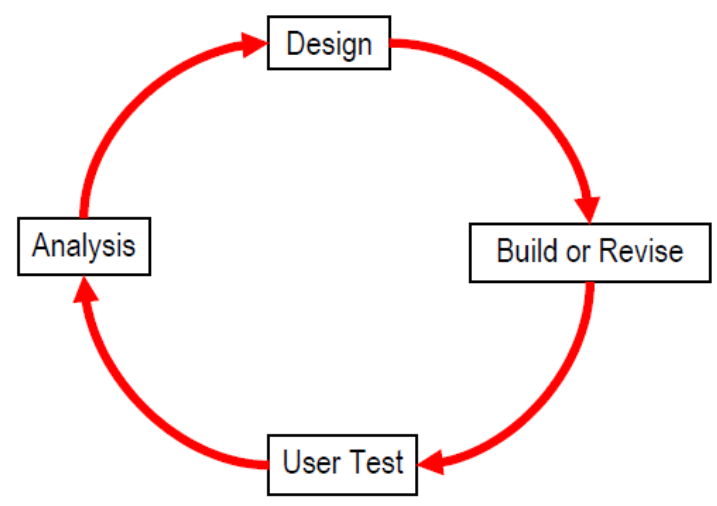

Gambar 1. Proses User Centered Design [3]

IBM UCD development community, sebuah komunitas penelitian terkemuka yang berfokus pada UCD, menjelaskan bahwa prinsip UCD terdiri dari enam [3]. (1) set the business goals; (2) understand the user; (3) Assessing competitiveness; (4) designing the total user experience; (5) Evaluating the design (6) Maintenance and support.

Prinsip pertama 'Menetapkan tujuan bisnis' berarti mencakup semua aspek bisnis perangkat lunak. Itu harus mempertimbangkan pasar di mana sistem akan digunakan, pengguna yang akan mengoperasikan sistem atau yang disebut intended user, dan kompetisi pada sistem sejenis lainnya.

Prinsip yang kedua 'memahami pengguna'. Hal ini berfokus pada mendengarkan kebutuhan pengguna dan permintaan pasar. Untuk melakukan hal ini, pengembang software harus menyertakan pengguna dalam proses desain. Dengan kata lain pengguna harus didengar dan dicermati kebutuhannya karena akan menjadi bahan utama untuk merancang seluruh sistem. Prinsip ini hampir tidak dipertimbangkan 
dalam pendekatan lainnya, karena membutuhkan usaha, uang, waktu, dan pengetahuan yang paling besar.

Prinsip 'menilai daya saing' berfokus pada pengujian sistem oleh pengguna, dengan melakukan perbandingan pengguna melaksana-kan tugas pada sistem yang sedang dirancang dengan milik pesaing. Perbandingan atau pengujian ini dilakukan dalam rangka untuk menghasilkan sistem yang lebih baik.

Yang keempat adalah prinsip 'merancang total pengalaman pengguna' atau membuat pengguna senang dengan produk dan bangga memilikinya. Ini berfokus pada aspek internal dan eksternal seperti dokumentasi, peningkatan, dukungan, instalasi, iklan dan lainnya. Ini dimaksudkan untuk dipertimbangkan oleh tim desain dan penting untuk memberikan yang baik kesan produk ke pelanggan atau pengguna, sehingga kepuasannya.

Selanjutnya 'Mengevaluasi desain'. Pertama, desain lengkap diberikan kepada pengguna untuk mengetes. Ini disebut prototipe perangkat lunak. Prototipe dan rilis selalu diberikan pada iterasi dan umpan balik yang diterima dari pengguna setelah iterasi digunakan untuk memperbaiki desain dan pengembangan iterasi berikutnya atau rilis.

Yang terakhir ialah prinsip 'Pemeliharaan dan dukungan'. Ini berfokus pada aspek yang perlu dipertimbangkan setelah produk telah disampaikan. Kita semua tahu bahwa tidak ada hal seperti itu sebagai sempurna perangkat lunak; ini adalah mengapa perawatan dan dukungan harus ada bersama dengan dokumentasi dalam rangka memecahkan masalah tak terduga. Ini juga harus mencakup mendengarkan pengguna dan menonton mereka dan menggunakan umpan balik mereka untuk membuat sistem yang lebih baik.

\subsection{Metode Prototyping}

Prototyping merupakan suatu metode pengembangan sistem yang menggunakan pendekatan untuk membuat sesuatu program dengan cepat dan bertahap sehingga segera dapat dievaluasi oleh pemakai [2]. Prototipe mewakili model produk yang akan dibangun atau mensimulasikan struktur, fungsionalitas dan operasi sistem.

Dimensi Prototyping [2] terdiri dari (1) Penyajian, yaitu bagaimana desain dilukiskan atau diwakili? Dapat berupa uraian tekstual atau dapat visual dan diagram. (2) Lingkup, yaitu apakah hanya interface atau mencakup komponen komputasi?; (3) Executability (Dapat dijalankan). Jika dikodekan, apakah akan ada periode saat prototype tidak dapat dijalankan? (4) Maturation yaitu tahapantahapan pengembangan produk. Ada dua tahap yakni secara (a) revolusioner: mengganti yang lama. Jika dirasa sistem yang lama sudah tidak dapat mengikuti perkembangan teknologi. (b) Evolusioner : terus melakukan perubahan pada perancangan yang sebelumnya

\section{HASIL DAN PEMBAHASAN}

\subsection{Goal Statement}

Website ini merupakan jenis website ecommerce, yang ditujukan sebagai solusi untuk membantu perusahaan atau pengusaha dalam mengembangkan usahanya dan menghadapi tekanan bisnis. Website CakeCorner.com dibuat untuk memudahkan penjual mempro-mosikan produknya ke masyarakat yang lebih luas, dan memudahkan masyarakat untuk membeli berbagai jenis kue tanpa harus keluar rumah ataupun masyarakat yang waktu senggangnya sedikit.

\subsection{Sudut Pandang Perancangan Desain}

Dalam membuat prototype untuk website CakeCorner ini, pembuat memakai sudut pandang UCD (User Centered Design), dimana pengguna ditempatkan di tengah proses desain, dari analisis awal kebutuhan pengguna untuk pengujian dan evaluasi. Prototype ini mendukung tujuan dengan memungkinkan pengguna melihat \& mengalami sistem final jauh sebelum itu dibangun.

\subsection{Model Konseptual}

Model konseptual yang digunakan adalah process oriented, karena website ini bertujuan untuk tempat sarana menjual suatu produk [4]. Penjual mengarahkan pembeli atau pengunjung web melihat-lihat berbagai macam produk yang dijual melalui menu (button) Gallery. Proses selanjutnya adalah penjual atau pengunjung membeli produk melalui form Order.

\subsection{Tools Yang Digunakan}

Tools yang digunakan dalam pengerjaan prototype design adalah CorelDRAW X7

\subsection{Desain User Interface Web}


Pada perancangan antarmuka web CakeCorner.com ini menerapkan kaidah perancangan "8 Golden Rules User Interface Design". Aturan yang pertama adalah Strive For Consistency, diterapkan pada halaman web yang menggunakan hanya satu warna utama yaitu Martian green, yang cukup netral sehingga cocok untuk semua kalangan.

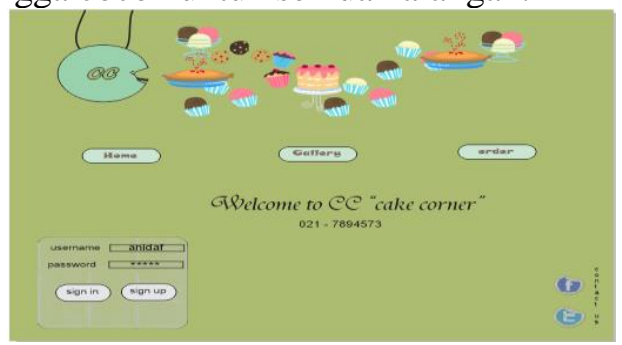

Gambar 2. Halaman Home

Halaman utama terdiri dari menu Home, Gallery, dan Order. Pada halaman tersebut juga terdapat form untuk login bagi member. Dibawah tulisan Welcome to CC "Cake Corner 021-7633654" terdapat ruang kosong untuk menampilkan galeri foto dan form untuk pesan (order).

Aturan yang kedua ialah Enable Frequent Users to Use Shortcuts. Pengguna diberikan kemudahan untuk menuliskan nama produk yang akan dipesan tanpa perlu melihat-lihat galeri produk.

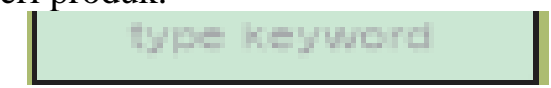

Gambar 3. Shortcut Untuk Memilih Produk

Aturan yang ketiga ialah Offer Informative Feedback. Salah satu umpan balik yang informatif bagi pengguna adalah sistem memberitahukan ketika terjadi kegagalan pendaftaran member.

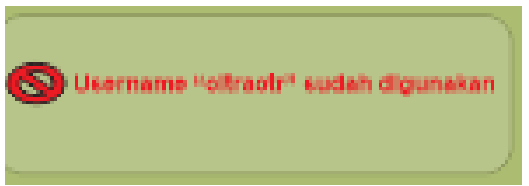

Gambar 4. Umpan Balik Saat Gagal Sign Up

Aturan yang keempat ialah Design Dialogs to Yields Closure. Prinsip ini adalah mengenai 'adanya panduan yang memudahkan user untuk melewati kegiatan yang memiliki banyak tahap'. Dan adanya keterangan atau 'feedback' di setiap tahap, yang dapat memberitahukan bahwa tahap ini sudah selesai dan komplit.

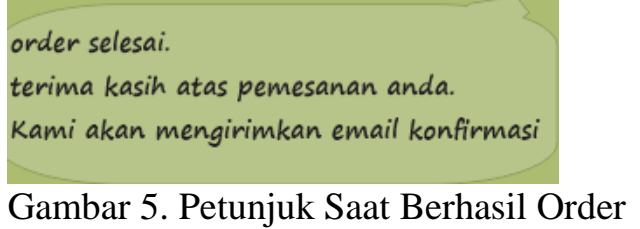

Aturan kelima ialah Offer error prevention \& simple error handling. Pada saat terdapat kesalahan pada login, lupa password, user dapat mengetahui nya kembali dengan meng-klik 'forgot password'. Sistem akan mengirimkan ke email user, username dan password baru.

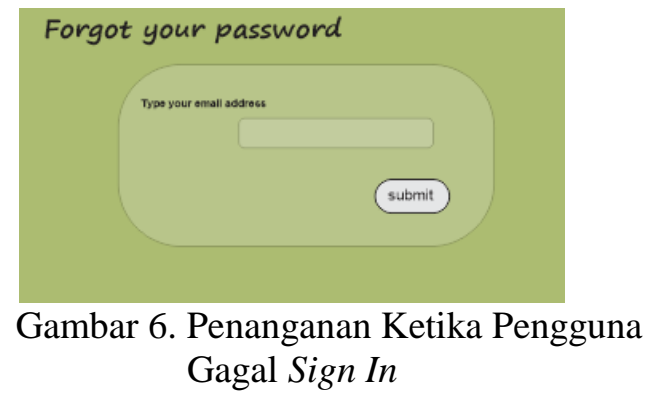

Aturan keenam adalah Permit Easy Reversal of Action. Sistem memberikan kemudahan bagi pengguna untuk membatakan tindakan yang sudah dilakukan dengan meng-

klik tombol $\rightarrow$ (Undo) atau menekan secara bersamaan tombol Ctrl $+\mathbf{z}$.

Penerapan aturan berikutnya yaitu Support Internal Locus of Control, adalah adanya menu-menu yang bebas dipilih user, sehingga user memiliki kontrol terhadap sistem

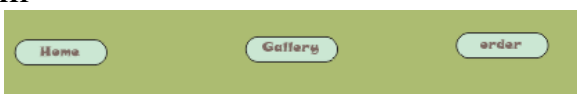

Gambar 7. Pilihan Menu

Aturan selanjutnya adalah Reduce Shortterm memory load. Untuk mengurangi beban memori jangka pendek, menu - menu yang ditampilkan didesain dengan sederhana dan tidak banyak gambar yang ditampilkan. Hal ini membuat pengguna fokus pada proses pemilihan produk (menu gallery) dan proses pemesanan produk (menu order). 


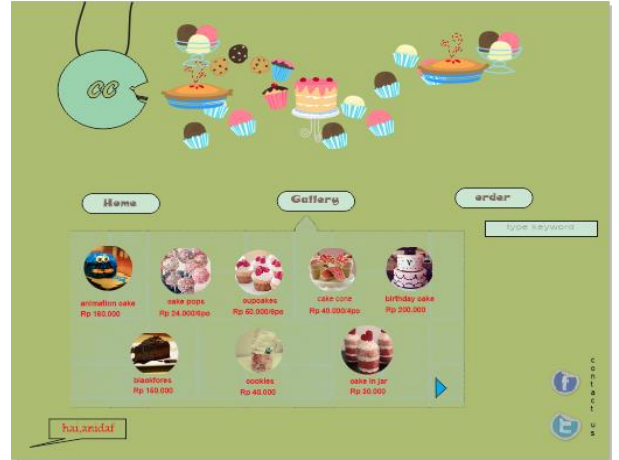

Gambar 8. Halaman Gallerry

Pada gambar 8 terdapat tombol dengan warna lebih terang dan mencolok sehingga pengguna dipastikan mengetahui bahwa tombol tersebut adalah tombol Next (menuju halaman selanjutnya).

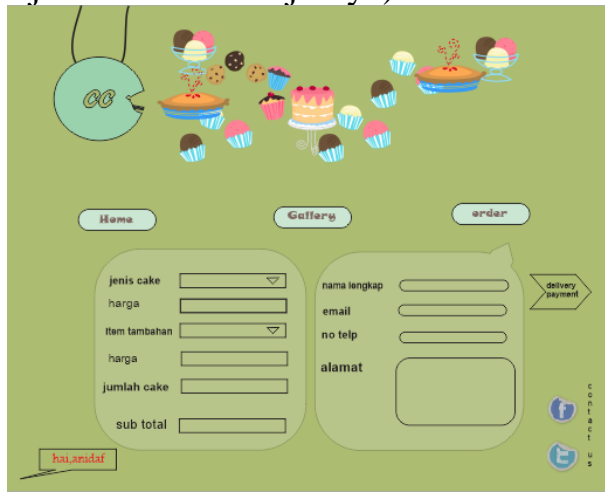

Gambar 9. Halaman Order

Icon $\sum_{\substack{\text { deliveny } \\ \text { payment }}}$ yang terdapat di halaman order, bisa diklik hanya jika data-data penting sudah terisi. Posisi icon tersebut diletakan disebelah kanan dari bubble 2 karena icon ini akan diklik setelah data penting terisi semua,dan umumnya orang melihat dan mengisi dari sebelah kiri baru ke kanan. Pemilihan bentuk icon dengan panah, dimaksudkan untuk menegaskan bahwa akan ke proses selanjutnya dari rangkaian order tersebut.

Setelah prototipe desain antarmuka tersebut sudah selesai dilakukan maka dibuatlah sebuah pengujian atau testing. Pada pengujian tidak melibatkan real user melainkan membuat sebuah skenario tugas (task-based scenario) yang digunakan oleh pengembang desain antarmuka untuk menguji apakah semua task yang dibutuhkan pengguna sudah tercakup pada desain tersebut.
Pendekatan user-centered design (UCD) digunakan untuk membuat prototipe desain antarmuka pengguna. Proses yang dilakukan adalah melakukan analisa yang terdiri dari (1) menyusun goal statement dan model konseptual. Selanjutnya membuat desain dengan menerapkan 8 aturan emas. Langkah ketiga adalah melakukan pengujian dengan metode task-based scenario, yaitu pengujian yang dilakukan oleh pengembang tanpa melibatkan real user. Dari pengujian tersebut akan dilakukan redesign jika terdapat revisi pada desain yang telah disepakati.

\section{DAFTAR PUSTAKA}

[1] Hanna Strömberg, Jaana Leikas, Veikko Ikonen. Netta Iivari, Timo Jokela, KariPekka, Aikio, et all. UserCentred Design Guidelines for Methods and Tools VTT Information, Finlandia: VTT Information Technology University of Oulu, Dept. of Information processing science, Philips Research Philips Applied Technologies, 2005.

[2] Jennifer Preece, Yvonne Rogers, Helen Sharp. Interaction design : beyond humancomputer interaction, America: John Willey\&Sons, 2002.

[3] Ameri, Shahriar. User-Centered Design, Concordia University. 2003.

[4] Kangas, Eeva, Timo Kinnunen. Applying User-Centered Design to Mobile Application Developmentser-Centered Design, Communications Of The Acm. 2005.

\section{PENUTUP}


